\title{
INTERVENSI PROGRESSIVE MUSCLE RELAXATION LEBIH MENURUNKAN TEKANAN DARAH DARI PADA SLOW STROKE BACK MASSAGE PADA PASIEN HIPERTENSI DERAJAT I YANG MENGONSUMSI OBAT ANTI HIPERTENSI DI BADUNG
}

\author{
Ni Komang Ayu Juni Antari'1, Alex Pangkahila², Muh. Ali Imron ${ }^{3}$, I Putu Adiartha Griadhi', \\ Luh Made Indah Sri Handari Adiputra ${ }^{5}$, Muh. Irfan ${ }^{6}$ \\ ${ }^{1}$ Program Studi Magister Fisiologi Olahraga Universitas Udayana Bali \\ ${ }^{2,4,5}$ Fakultas Kedokteran Universitas Udayana Bali \\ ${ }^{3,6}$ Program Studi Sarjana dan Profesi Fisioterapi, Fakultas Ilmu Kesehatan, \\ Universitas Aisyiyah Yogyakarta
}

\begin{abstract}
ABSTRAK
Pendahuluan: Latihan fisik pada pasien hipertensi adalah teknik relaksasi yang sudah dibuktikan memiliki efek positif dalam menurunkan tekanan darah. Tujuan: Tujuan penelitian ini adalah untuk mengetahui intervensi progressive muscle relaxation (PMR) lebih menurunkan tekanan darah daripada intervensi slow stroke back massage (SSBM) pada pasien hipertensi derajat I di Badung. Metode: Eksperimental Pre dan post test control group design menggunakan 24 subjek, terbagi dalam 2 kelompok, kelompok perlakuan I $(\mathrm{n}=12)$ mendapatkan intervensi slow stroke back massage sedangkan kelompok perlakuan II $(\mathrm{n}=12)$ mendapatkan intervensi progressive muscle relaxation. Intervensi diberikan 3x seminggu selama 4 minggu.Ssphygmomanometer dan stethoscope digunakan untuk melakukan pengukuran tekanan darah. Hasil: Uji Independent Sample $T$-test menunjukkan adanya perbedaan yang bermakna antara KP I dan KP II dengan $(\mathrm{p}<0,05)$ untuk tekanan darah sistolik dan diastolik. Simpulan: Intervensi progressive muscle relaxation lebih menurunkan tekanan darah dari pada intervensi slow stroke back massage pada hipertensi derajat I yang mengonsumsi obat anti hipertensi di Badung.
\end{abstract}

Kata kunci: progressive muscle relaxation, slow stroke back massage, hipertensi derajat I, tekanan darah 


\title{
THE INTERVENTION OF PROGRESSIVE MUSCLE RELAXATION IS \\ MORE DECREASING BLOOD PRESSURE THAN SLOW STROKE BACK MASSAGE OF GRADE I HYPERTENSION PATIENS WHOSE CONSUMED ANTI-HYPERTENSION MEDICINE IN BADUNG REGENCY
}

\begin{abstract}
ABTSRACT
Introduction: Physical exercise as anticipate of hypertension along with nutrition and medicines. One of physical exercise that can be applicated here is relaxation techniques which is showed positive impact in decreased blood pressure. Objective: Determine the difference between PMR intervention with SSBM intervention to reduce blood pressure for grade I hypertension patients whose consumed anti-hypertension medicine in badung regency. Methods: Experimental method Pre and post-test control group design and used 24 subjects, divided in to 2 groups, in which the experimental group I $(n=12)$ received progressive muscle relaxation (PMR) while the treatment group $2(n=12)$ received slow stroke back massage (SSBM). Intervention is given 3 times a week for 4 weeks. This study was using simple random sampling. Blood pressure was measured by sphygmomanometer and stethoscope. Result: Independent Sample T-test showed there was significant difference between Group 1 and Group 2 which $(\mathrm{p}<0.05)$ for systolic and diastolic blood pressure. Conclusion: Progressive muscle relaxation intervention decrease blood pressure more than slow stroke back massage intervention in patients grade I hypertension whose consumed antihypertension medicine in Badung Regency.
\end{abstract}

Keywords: progressive muscle relaxation, slow stroke back massage, grade I hypertension, blood pressure 


\section{PENDAHULUAN}

Stres dikatakan memiliki hubungan dengan peningkatan tekanan darah. Secara fisiologis, sistem simpatis serta korteks adrenal akan terstimulasi saat stres melalui aktivasi hipotalamus dengan respons aktivasi organ dan otot polos. Epinefrin dan norepinefrin juga akan dilepaskan oleh saraf simpatis dalam keadaan stres. ${ }^{1,2}$

Klien dengan hipertensi dapat melakukan pengontrolan tekanan darah dengan melakukan modifikasi gaya hidup dan latihan relaksasi. ${ }^{3}$ Saat tubuh individu dalam keadaan rileks maka akan terjadi relaksasi juga pada pembuluh darah dan otot tubuh. Penurunan epinefrin dan norepinefrin memiliki peran selama melakukan teknik relaksasi dengan maksud untuk menurunkan tekanan darah ${ }^{4}$

Teknik relaksai yang diaplikasikan adalah stimulasi kutaneus yaitu Slow Stroke Back Massage (SSBM dan Progressive Muscle Relaxation (PMR).

Berdasarkan hal tersebut, penulis ingin melakukan penelitian untuk membandingkan efektivitas intervensi SSBM dengan PMR dalam menurunkan tekanan darah.

\section{METODE PENELITIAN}

\section{A. Rancangan Penelitian}

Rancangan eksperimental menggunakan pre and post-test control group design

\section{B. Tempat dan Waktu Penelitian}

Praktik bersama dokter umum dan fisioterapi Bernasi Badung, Bali, selama tiga bulan terhitung mulai awal bulan Januari 2018 sampai bulan Maret 2018. Intervensi terapi setiap sampel penelitian dilakukan selama empat minggu dimana tiga kali dalam seminggu.

\section{Populasi dan Sampel}

Populasi terjangkau yaitu pasien hipertensi derajat I yang berobat di praktik bersama dokter umum dan fisioterapi Bernasi di Badung, Bali.

\section{Teknik Pengambilan Sampel}

Simple random sampling dilakukan untuk pengambilan sampel, kemudian teknik blocked randomization dilakukan untuk merandomisasi sampel.

\section{E. Prosedur Penelitian}

1) Prosedur Pendahuluan :

a. Melakukan proses pengajuan ethical clearance ke bagian Litbang FK Unud/ RSUP Sanglah.

b. Melakukan proses perijinan pada tempat penelitian.

c. Penyebaran inform consent yang harus ditandatangani subjek penelitian.

d. Pengukuran tekanan darah dengan sphygmomanometer dan stethoscope dilakukan sebelum dan sesudah intervensi pada kedua kelompok.

2) Prosedur Pelaksanaan Pengukuran Tekanan Darah

Pengukuran tekanan darah dilakukan langsung oleh dokter yang bertugas di klinik tempat penelitian dengan menggunakan alat sphygmomanometer dan stethoscope. Pengukuran ini dilakukan sebelum intervensi pertama dan sesudah intervensi ke 12 .

3) Prosedur Pelaksanaan SSBM

Adapun teknik pengaplikasian SSBM, sebagai berikut: Massage lakukan pada punggung $5 \mathrm{~cm}$ dari procesus spinosus dengan memberikan usapan yang lembut dan berirama. Usapan dilakukan dari leher hingga area sacrum selama 10 menit. Intervensi ini akan dilakukan oleh peneliti yang juga dibantu oleh petugas lapangan, dalam satu hari setiap terapis maksimal melakukan intervensi sebanyak 4 sampel.

4) Prosedur Pelaksanaan PMR

Pada setiap kali perlakuan PMR dilakukan selama 10 meni, terdiri dalam 15 jenis gerakt. Untuk setiap gerakan posisi sampel dipertahankan selama 5 detik, kemudian relaksasi 10 detik dan diulang sebanyak 2 kali.

\section{F. Analisis Data}

Langka-langkah analisis data sebagai berikut: 
1. Umur, jenis kelamin, IMT dan obat anti hipertensi yang dikonsumsi sampel menggunakan statistik deskriptif.

2. Saphiro Wilk Test digunakan untuk menguji nilai normalitas pada masingmasing kelompok.

3. Leven's Test digunakan untuk menguji homogenitas data.

4. Paired Samples T-test digunakan untuk menguji komaparasi data pada kelompok berpasangan.

5. Independent Sample T-test digunakan untuk menguji komaparasi data pada kelompok tidak berpasangan.

\section{HASIL PENELITIAN}

\section{Data Karakteristik Sampel}

Tabel 1 menunjukkan karakteristik sampel penelitian.

Tabel 1

Distribusi Data Sampel

\begin{tabular}{ccc}
\hline Karakteristik & $\begin{array}{c}\text { KP I } \\
(\mathbf{n = 1 2})\end{array}$ & $\begin{array}{c}\text { KP II } \\
(\mathbf{n = 1 2})\end{array}$ \\
\hline Jenis Kelamin $(\%)$ & & \\
Laki-laki & 33,3 & 41,7 \\
Perempuan & 66,7 & 58,3 \\
Obat Anti & & \\
hipertensi $(\%)$ & & 0 \\
CCB & 0 & 100 \\
ACE inhibitor & 100 & $49,75 \pm 1,485$ \\
Usia (tahun) & $49,83 \pm 1,267$ & \\
Mean \pm SD & & \\
IMT $\left(\mathrm{kg} / \mathrm{m}^{2}\right)$ & $21,25 \pm 0,747$ & $21,24 \pm 0,745$ \\
Mean \pm SD & & \\
\hline
\end{tabular}

Pada KP I, sampel laki-laki berjumlah empat orang dan sampel perempuan berjumlah delapan orang. Pada KP II, lima sampel laki-laki dan tujuh sampel perempuan, jumlah keseluruhan sampel adalah 24 orang.

\section{Uji Normalitas dan Homogenitas}

Tabel 2

Hasil Uji Normalitas dan Uji Homogenitas

\begin{tabular}{|c|c|c|c|c|c|c|}
\hline & \multicolumn{4}{|c|}{$\begin{array}{c}\text { Uji Normalitas } \\
\text { Saphiro-Wilk Test }\end{array}$} & \multicolumn{2}{|c|}{$\begin{array}{c}\text { Uji } \\
\text { Homogenitas } \\
\text { Levene's Test }\end{array}$} \\
\hline & \multicolumn{2}{|c|}{ KP I } & \multicolumn{2}{|c|}{ KP II } & \multirow[b]{2}{*}{$\begin{array}{l}\text { Sistol } \\
\text { ik }\end{array}$} & \multirow[b]{2}{*}{$\begin{array}{l}\text { Diast } \\
\text { olik }\end{array}$} \\
\hline & $\begin{array}{l}\text { Sistol } \\
\text { ik (p) }\end{array}$ & $\begin{array}{l}\text { Diast } \\
\text { olik } \\
\text { (p) }\end{array}$ & $\begin{array}{c}\text { Sistoli } \\
\mathrm{k}(\mathrm{p})\end{array}$ & $\begin{array}{l}\text { Diast } \\
\text { olik } \\
\text { (p) }\end{array}$ & & \\
\hline $\begin{array}{c}\text { Rerata } \\
\text { Sebelu } \\
\text { m }\end{array}$ & 0,224 & 0,064 & 0,105 & 0,066 & 0,692 & 0,653 \\
\hline $\begin{array}{c}\text { Rerata } \\
\text { Sesudah }\end{array}$ & 0,210 & 0,187 & 0,099 & 0,123 & 0,514 & 0,286 \\
\hline
\end{tabular}

Terlihat dalam Tabel 2 hasil uji Shapiro Wilk Test didapatkan nilai probabilitas $\mathrm{p}>0,05$ pada KP I dan KP II, sehingga data KP I dan KP II berdistribusi normal dan uji statistik selanjutnya menggunakan uji parametrik.

\section{Uji Komparasi Penurunan Tekanan Darah Sebelum dan Sesudah pada Setiap Kelompok}

Paired Sample T-test digunakan untuk uji hipotesis pada KP I dan KP II.

Tabel 3

Uji Rerata Penurunan Tekanan Darah pada KP I

\begin{tabular}{cccc}
\hline & Pre test & Post test & \\
\cline { 2 - 3 } & $\begin{array}{c}\text { Mean } \pm \text { SD } \\
(\mathbf{m m H g})\end{array}$ & $\begin{array}{c}\text { Mean } \pm \text { SD } \\
(\mathbf{m m H g})\end{array}$ & \\
\hline \multirow{2}{*}{ Sistolik } & $141,83 \pm$ & $136,92 \pm$ & \multirow{2}{*}{0,000} \\
\multirow{2}{*}{ Diastolik } & 1,586 & 1,881 & \\
& $91,25 \pm$ & $85,83 \pm$ & 0,000 \\
& 1,138 & 1.403 & \\
\hline
\end{tabular}

Pada KP I didapatkan data tekanan darah sistolik dan disatolik yaitu $p<0,05$. 
Tabel 4

Uji Rerata Penurunan Tekanan Darah pada KP II

\begin{tabular}{lccc}
\hline & Pre test & Post test & \\
\cline { 2 - 3 } & $\begin{array}{c}\text { Mean } \pm \text { SD } \\
(\mathbf{m m H g})\end{array}$ & $\begin{array}{c}\text { Mean } \pm \text { SD } \\
(\mathbf{m m H g})\end{array}$ & Nilai p \\
\hline Sistolik & $142,33 \pm$ & $\begin{array}{c}135,25 \pm \\
1,422\end{array}$ & 0,000 \\
Diastolik & 1,303 & $84,33 \pm$ & 0,000 \\
& $91,17 \pm 1,030$ & 1,073 & \\
\hline
\end{tabular}

Pada KP II didapatkan data tekanan darah sistolik dan disatolik dengan nilai $\mathrm{p}<0,05$.

\section{Uji Komparasi Penurunan Tekanan Darah pada Kelompok Perlakuan I dan Kelompok Perlakuan II}

Independent Sample T-test digunakan ntuk menguji perbandingan penurunan tekanan darah antar kelompok perlakuan.

Tabel 5

Uji Komparasi Penurunan Tekanan Darah Sistolik

\begin{tabular}{lccc}
\hline & Kelompok & $\begin{array}{c}\text { Mean } \pm \mathrm{SD} \\
(\mathrm{mmHg})\end{array}$ & Nilai $\mathrm{p}$ \\
\hline Pre test & KP I & $141,83 \pm 1,586$ & 0,408 \\
& KP II & $142,33 \pm 1,303$ & \\
& KP I & $136,92 \pm 1,881$ & \\
Post tes & KP II & $135,25 \pm 1,422$ & \\
& & & \\
\hline
\end{tabular}

Nilai post tes menunjukkan $\mathrm{p}<0,05$, hal tersebut menunjukkan perbedaan penurunan tekanan darah sistolik yang bermakna setelah intervensi antara KP I dan KP II.

Tabel 6

Uji Komparasi Penurunan Tekanan Darah Diastolik

\begin{tabular}{cccc}
\hline & Kelompok & $\begin{array}{c}\text { Mean } \pm \text { SD } \\
(\mathbf{m m H g})\end{array}$ & Nilai p \\
\hline Pre test & KP I & $91,25 \pm 1,138$ & 0,853 \\
\hline
\end{tabular}

KP II

$91,17 \pm 1,030$

$\begin{array}{llll} & \text { KP I } & 85,83 \pm 1,403 & 0,008 \\ \text { Post tes } & \text { KP II } & 84,33 \pm 1,073 & \\ & & \end{array}$

Nilai post tes menunjukkan $\mathrm{p}<0,05$, hal tersebut menunjukkan perbedaan penurunan tekanan darah diastolik yang bermakna setelah intervensi antara KP I dan KP II.

\section{PEMBAHASAN}

\section{Intervensi Slow Stroke Back Massage (SSBM) Menurunkan Tekanan Darah pada Kelompok Perlakuan I}

SSBM merupakan salah satu teknik relaksasi dengan stimulasi yang dilakukan pada kulit punggung dengan usapan yang perlahan yang menghasilkan stumulasi taktil sehingga memberikan respon neurohormonal. Stimulus tersebut diinterpretasikan sebagai respons relaksasi. Saraf parasimpatis merupakan bagian dari sistem saraf otonom yang memiliki peran paling besar dalam mekanisme massage ini terhadap penurunan tekanan darah. Terstimulasinya saraf parasismpatis akan menghasilkan asetilkolin, dimana asetil kolin ini dapat menghampat terjadinya depolarisasi yang terjadi pada SAnode dan juga menghampat terjadinya depolarisasi pada AVnode. Terjadinya hal tersebut tentunya akan berpengaruh juga terhadap kontraktilitas dari jantung sehingga terjadi penurunan kecepatan denyut dari jantung, penurunan curah jantung, terjadinya vasodilatasi secara sistemik dan penurunan dari volume sekuncup. Semua hal tersebut akan berdampak terhadap terjadinya penurunan tekanan darah dalam tubuh. ${ }^{5,6}$

Pemberian massage ini juga dapat menurunkan aktivitas dari gelombang $\alpha$ dan $\beta$, disisilain meningkatnya aktivitas gelombang $\delta{ }^{7,8}$ Respons positif ketika tubuh 
dalam keasaan nyaman dan rileks akan merangsang hipotalamus dan LC melalui jalur HPA aksi. Penurunan sekresi CRH akan terjadi oleh stimulasi dari hipotalamus. Selain itu ACTH juga akan menurun sehingga merangsang POMC yang akan meningkatkan produksi endorphin. LC memiliki peran terhadap efek dari stimulasi simpatis yaitu dengan merangsang penurunan AVP melalui penurunan sistesis norepinefrin. Ketika berkurangnya produksi dari ACTH dan AVP akan terjadi pula penurunan cardiac output dan tahanan perifer yang diiringi juga dengan penurunan tekanan darah. ${ }^{9}$

\section{Intervensi Progressive Muscle relaxation (PMR) Menurunkan Tekanan Darah pada Kelompok Perlakuan II}

PMR adalah jenis latihan relaksasi
dengan proses menegangkan dan merelaksasikan otot tubuh dan dalam gerakan PMR terdapat komponen latihan deep breathing. Peran dari saraf parasimpatis juga memegang peranan dalam mekanisme latihan ini. Hormon asetilkolin dapat mempengaruhi permeabilitas terhadap ion kalium yang mengakibatkan terjadinya hiperpolarisasi sehingga dalam keadaan ini akan terjadi penurunan potensial membran. Terjadinya hal tersebut selanjutnya akan berdampak terhadap terjadinya penurunan irama dari nodus sinus pada jantung dan berkurangnya eksitabilitas dari serabut atrium dan nodus dari AV, sehingga terntunya juga akan mempengaruhi perjalanan dari impuls jantung yaitu menjadi lebih lambat menuju ventrikel. ${ }^{10}$

Disisi lain juga terjadi regangan arteri sehingga dapat terjadi vasodilatasi pada arteri dan juga pada vena yang juga difasilitasi oleh pusat vasomotor dari otak, salah satun yang difasilitasi oleh vasomotor adalah adalah refleks baroreseptor. Saat relaksasi Refleks baroreseptor akan mengurangi aktivitas dari system saraf simpatis dan juga mempengaruh perodukssi dari epinefrin yaitu terjadi penurunan serta terjadi hal yang terbalik pada system saraf parasimpatis yaitu peningkatan pada system saraf parasimpatis yang tentunya juga akan berpengaruh terhadap penurunan kecepatan denyut dari jantung, penurunan volume sekuncup, dna jug mengakibatkan vasodilatasi pembuluh darah sehingga terjadi penurunan tekanan darah. ${ }^{3}$

\section{Intervensi Progressive Muscle Relaxation Lebih Menurunkan Tekanan Darah daripada Intervensi Slow Stroke Back Massage}

Didapatkan hasil Independent Sample T-test pada penelitian kali ini yaitu $\mathrm{p}<0,05$ pada tekanan darah sistolik maupun diastolik, berarti terdapat perbedaan penurunan tekanan darah yang bermakna anata kedua kelompok perlakuan tersebut. Pada KP PMR terjadi penurunan yang lebih besar dibandingkan pada KP SSBM.

Pada penelitian ini PMR lebih menurunkan tekanna darah dibandingkan SSBM, jika dikaji dapat diakibatkan oleh karena mekanisme PMR dalam menurunkan tekanan darah erat kaitannya dengan manajemen stres, baik fisik maupun psikologis. Ketika tubuh dalam kondisi stres muncullah hormon noradrenalin. ${ }^{11,12}$

Didalam intervensi PMR terdapat juga komponen latihan deep breathing sehingga selain mekanisme yang sudah dijelaskan sebelumnya, PMR memiliki mekanisme tambahan dalam menurunkan tekanan darah yaitu melalui deep breathing.

Deep breathing akan menghambat sinyal yang diberikan dari reseptor regang, karena selama inspirasi dalam akan terjadi peregangan disekitar jaringan pada paru-paru. Ketika menarik nafas dalam akan mengakibatkan peregangan disekitar jaringan pada paru yang akan mengirimkan sinyal yaitu berupa inhibisi sehingga terjadi adaptasi yaitu slowly adapting stretch reseptors (SARs) dan juga pada fibriblas akan terjadi hoperpolarisasi. Adanya SARs dan hiperpolarisasi ini akan mempengaruhi aktivitas metabolic. Ketika terjadi peningkatkan aktivitas dari parasimpatis maka akan berdampak pada metabolik yaitu terjadinya penurunan dengut jantung, penurunan tekanan darah dan konsumsi O2. ${ }^{12}$ 
Peregangan yang terjadi pada dinding arkus aorta dan sinus karotis selanjutnya diteruskan oleh nernus vagus mejunu pusat regulasi kerdiovarkuler yang ada di medulla oblongata yang akan merespons untuk meningkatkan refleks dari baroreseptor. ${ }^{12}$

\section{SIMPULAN}

1. Intervensi $S S B M$ dapat menurunkan tekanan darah pada pasien hipertensi derajat I yang mengonsumsi obat anti hipertensi.

2. Intervensi $P M R$ dapat menurunkan tekanan darah pada pasien hipertensi derajat I yang mengonsumsi obat anti hipertensi.

3. Intervensi $P M R$ lebih menurunkan tekanan darah dari pada SSBM pada pasien hipertensi derajat I yang mengonsumsi obat anti hipertensi.

\section{DAFTAR PUSTAKA}

1. LeMone, P., Burke, K. 2008. Medical Surgical Nursing: Critical Thinking in Client Care. 4th Edition. New Jersey: Persone Prentice Hall.

2. Sherwood, L. 2010. Human Physiology : fromCellsto Systems. USA: Yolanda Cossio.

3. Black, J., Hawk, J. 2005. Medical Surgical Nursing Clinical Mnagement for Positive Outcome. 7th Edition. Philadelphia: Mosbi.

4. Shinde, N., Hande, D., Bhushan, V. 2013. Immediate Effect of Jacobson's Progressive Muscle Relaxation in Hypertension. Scholars Journal of Applied Medical Sciences (SJAMS), 3, 80-85.

5. Lawton, G. 2003. Toward a Neurophysiological Understanding of Manual Therapy Neuro-Manual Therapy. [Cited 2017 September 21]. Available From: http://www.americanmanualmedicine. com/educational/a14z2.html
6. Stein, R. 2004. Complementary and AlternativeCardiovascularMedicine. American: Human Press United Stages of America.

7. Molliver, D. C. 2005. ASIC3, An Acid-sensing Ion Channel, is Expressed in Metaboreceptive Sensory Neurons, Molecular Pain, Vol.1.

8. Valentino, R. J., Bockstaele, E. V. 2008. Convergen Regulation of LocusCoureleusActivity as An AdaptiveResponsse to Stres. [Cited 2017 Oktober 20]. Available From: http://www.ncbi.nlm.gov/pmc/aeticles /PMC2349983/

9. Guyton, A. C., Hall, J. E. 2008. Textbook of Medical Physiology. 11th Edition ed. Philadelphia: Elsevier Saunders.

10. Hamarno, R. 2010. Pengaruh Latihan Relaksasi Otot Progresif Terhadap Penurunan Tekanan Darah Klien Hipertensi Primer di Kota Malang. Tesis, Universitas Indonesia, Jakarta

11. Haruyama, S. 2011. The Miracle of Endorphin. Bandung: Mizan Media Utama.

12. Jerath, R., Edry, J. W., Barnes, V. A. and Jerath, V. 2006. Physiology of Long Pranayamic Breathing : Neural Respiratory Elementsmay Provide a Mechanism that Explains How Slow Deep Breathing Shifts The Autonomic Nervous System. [Cited 2018 Maret 20]. Available From: http://www.ncbi.nlm.nih.gov/pubmed/ 16624497 